\title{
Cultivation and acceptability of carrot cultivars'
}

\author{
Isabel Beauchamp de Caloni, Guillermo Fornaris-Rullán \\ and Lucas Avilés-Rodríguez ${ }^{2}$
}

\begin{abstract}
On the basis of organoleptic evaluation out of six carrot (Daveus carota L.) cultivars, Short 'n Sweet, Royal Chantenay, Royal Danvers and Texun were well accepted by a taste panel. The six carrot cultivars were planted at Fortuna Research and Development Center located in the south coast of Puerto Rico. Carrots were sensory evaluated raw and cooked fresh and affer storage af $7.2^{\circ} \mathrm{C}\left(45^{\circ} \mathrm{F}\right)$ for 30 days. Overall quality of the cultivars was found acteptable by the panel except for fresh and stored Casey raw, and Nuggeteer cooked.
\end{abstract}

\section{INTRODUCTION}

Among succulent vegetables, carrots (Daucus carota L.) rank third in world production. Although they are grown practically everywhere in the world, production is low in tropical regions (10). In Puerto Rico, carrots have been grown satisfactorily every month of the year at high and low elevations, but they grow best during the cool winter and spring seasons (9). At present, there is no commerical production of carrots in Puerto Rico.

The demand for high-quality vegetables, and the knowledge obtained from the research conducted in other countries where foods from plant origin are important sources of vitamins, led to the study of cultivation in other areas, It is well known that yellow and green vegetables are good sources of the much needed vitamin A, but low in calories. Their consumption in the daily diet is recommended for healthy skin, eyes and good digestion. A portion of $60 \mathrm{~g}$ or half a cup of shredded carrot gives an average of 6,000 International Units of vitamin A (1). This amount is enough for the recommended daily allowance by the National Research Council, Food and Nutrition Board (6). According to Fernández (2) no variation in $B$-carotene (provitamin $A$ ) occurs during seasonal changes in Puerto Rico. Carrot also supplements the diet with potassium and important fiber $(1,3)$.

${ }^{2}$ Manuscript submitted to Editorial Board October 20, 1986.

2 Food Researcher, Food Technology Laboratory, Research Assistant, Department of Horticulture, and former Agricultural Research Technician, Department of Horticulture, Agricultural Experiment Station, Mayagüez Campus, University of Puerto Rico, Río Piedras, P. R. 
TABLE 1.-Deseription of 6 carrot (Daucus carota $L$.) cultivars

\begin{tabular}{lrccc}
\hline & \multicolumn{3}{c}{ Root } & \\
\cline { 2 - 4 } \multicolumn{1}{c}{ Variety } & Length & Shoulder & Weight & Top \\
\hline Short'n Sweet & 8.72 & 2.48 & 93.32 & 34.70 \\
Royal Chantenay & 11.39 & 3.46 & 95.73 & 39.85 \\
Casey & 14.97 & 2.87 & 64.29 & 40.11 \\
Royal Danvers & 17.01 & 3.22 & 89.38 & 40.37 \\
Texun & 19.01 & 2.74 & 68.52 & 34.54 \\
Nuggeteer & 19.22 & 2.85 & 91.50 & 34.03 \\
\hline
\end{tabular}

The quality attributes of fresh horticultural erops such as color and texture can be measured by objective methods, but accurate determination of flavor quality requires the use of subjective methods such as sensory evaluation procedures (4). Therefore, carrot cultivars grown in Puerto Rieo were submitted for sensory evaluations by a taste panel to determine acceptability.

\section{MATERIALS AND METHODS}

In order to know the acceptability of carrots grown in Puerto Rico, six cultivars were planted November 16, 1984, at the Fortuna Research and Development Center, located on the south coast, now considered the main area for commercial production of vegetable crops. Cultivars planted included Short 'n Sweet, Royal Chantenay, Casey, Royal Danvers, Texun and Nuggeteer. Table 1 includes a brief description of each cultivar at harvest.

The carrots were grown in a San Antón clay loam, Mollisols, Fluventic Hapludolls (8), a nearly level soil on alluvial fans in the semiarid area.

Samples of each carrot cultivar were submitted for sensory evaluation by a trained taste panel fresh and after storage at $7.2^{\circ} \mathrm{C}\left(45^{\circ} \mathrm{F}\right)$ for 30 days. Evaluations were carried out with grated raw carrots based on the $+2,-2$ scale for overall acceptability, as well as with whole carrots cooked in boiling salted water, on the basis of a 6-point hedonic seale ranging from "like very much" to "dislike," in appearance, flavor, mouth feel (texture) and overall acceptability $(5,7)$.

\section{RESULTS AND DISCUSSION}

The following tabulation shows the sensory evaluation of raw fresh and stored carrot cultivars based on the $+2,-2$ scale for overall acceptability. All carrot cultivars were rated acceptable when fresh and after storage except for Casey which was unacceptable. Significant difference was observed at the $5 \%$ level $(\mathrm{P}=0.05)$ between Casey and all others. 
Mean values ${ }^{3}$

$\begin{array}{lcc}\text { Variety } & \text { Fresh } & \text { After storage } \\ \text { Casey } & 0.13 \mathrm{~b}^{4} & 0.14 \mathrm{~b}^{4} \\ \text { Royal Chantenay } & 1.13 \mathrm{a} & 1.14 \mathrm{a} \\ \text { Royal Danvers } & 1.38 \mathrm{a} & 0.86 \mathrm{a} \\ \text { Texun } & 1.25 \mathrm{a} & 1.00 \mathrm{a} \\ \text { Nuggeteer } & 0.75 \mathrm{a} & 0.57 \mathrm{a} \\ \text { Short'n Sweet } & 0.88 \mathrm{a} & 1.00 \mathrm{a}\end{array}$

The following tabulation shows the evaluation of appearance of whole carrot cultivars. The scores are the sum of ranks per cultivar fresh and after storage. Nuggeteer was rated inferior in appearance at the 5\% probability level both fresh and stored. Casey and Royal Chantenay were found superior, whereas carrots of the Texun selection were rated at the $5 \%$ level inferior in appearance after storage. No significant difference was observed among the other carrots evaluated.

$\begin{array}{lcc}\text { Variety } & \text { Fresh } & \text { Stored } \\ \text { Casey } & 22 \mathrm{a}^{6} & 15 \mathrm{a}^{\mathrm{6}} \\ \text { Royal Chantenay } & 28 \mathrm{a} & 14 \mathrm{a} \\ \text { Royal Danvers } & 38 \mathrm{a} & 27 \mathrm{~b} \\ \text { Texum } & 31 \mathrm{a} & 45 \mathrm{c} \\ \text { Nuggeteer } & 45 \mathrm{~b} & 38 \mathrm{c} \\ \text { Short'n Sweet } & 25 \mathrm{a} & 29 \mathrm{~b}\end{array}$

Table 2 shows a detailed evaluation of cooked carrot, fresh and after storage. All fresh carrots were well accepted in appearance. After storage, carrot from Royal Danvers and Texun selections were the lowest scored, significantly different at the $5 \%$ level from all other cultivars. The highest scored were Casey, Nuggeteer and Short ' $n$ Sweet both fresh and stored. No significant difference in flavor was observed among fresh and stored carrots. Rating in flavor ranged from "like moderately" to "neither like or dislike."

No significant difference in texture was reported among the fresh carrots; whereas stored Casey was significantly different at the $5 \%$ level from Royal Danvers, Nuggeteer and Short 'n Sweet.

Regarding overal acceptability, significant difference at the $5 \%$ level was observed between cultivars Casey and Nuggeteer after storage. No

${ }^{3}+2,-2$ seale $-+2=$ very acceptable; $+1=$ acceptable; $0=$ questionable; $-2=$ not acceptable.

4 Means in columns followed by a common letter do not differ significantly at $\mathrm{P} \leq 0.05$.

${ }^{5}$ Scores based on Rank Totals - Superior - Inferior.

${ }^{\text {g }} \mathrm{Ranks}$ followed by a letter in common do not differ significantly at $5 \%$ level $(\mathrm{P} \leq 0.05)$. 
TABLE 2.-Sensory evaluation of carrot varieties fresh and after storage, cooked

\begin{tabular}{|c|c|c|c|c|c|c|c|c|}
\hline \multirow{3}{*}{ Variety } & \multicolumn{8}{|c|}{ Mean values ${ }^{2}$} \\
\hline & \multicolumn{2}{|c|}{ Appearance } & \multicolumn{2}{|c|}{ Flavor } & \multicolumn{2}{|c|}{ Texture } & \multicolumn{2}{|c|}{ Overall acceptability } \\
\hline & Fresh & Stored & Fresh & Stored & Fresh & Stored & Fresh & Stored \\
\hline Royal Chartenay & 4.90 & $5.18 \mathrm{a}$ & 3.90 & 4.27 & 4.60 & $4.64 \mathrm{ab}$ & 4.10 & $4.27 \mathrm{ab}$ \\
\hline Royal Danvers & 5.14 & $4.86 \mathrm{~b}$ & 4.14 & 3.86 & 4.57 & $3.71 \mathrm{~b}$ & 4.14 & $3.71 \mathrm{ab}$ \\
\hline Texun & 5.20 & $3.91 \mathrm{~b}$ & 4.20 & 4.00 & 4.30 & $4.91 \mathrm{ab}$ & 3.90 & $4.09 \mathrm{ab}$ \\
\hline
\end{tabular}

${ }^{2} 6$-point hedonic seale $-6=$ like very much; $1=$ do not like.

${ }^{2}$ Means in columns followed by one or more letters in common do not differ significantly at $\mathrm{P} \leq 0.05$. 
TABLE 3.-Sensory evaluation of carrots fresh and after storage by appectrance, flavor, teathure and overall acceptability, cooked

\begin{tabular}{lcccc}
\hline & \multicolumn{4}{c}{ Mean values } \\
\cline { 2 - 5 } Treatment & Appearance & Flavor & Texture & Overall acceptability \\
\hline Fresh & 5.19 & 4.04 & 4.59 & 4.06 \\
Stored & 5.00 & 3.94 & 4.48 & 3.91 \\
\hline
\end{tabular}

${ }^{16}$ - point bedonic scale: $6=$ like very mueb; $1=$ do not like.

significant difference in overall acceptability was reported among fresh carrots.

The sensory evaluation of all cooked fresh and stored carrots is presented on table 3 . No significant difference was observed in appearance, flavor, texture and overall acceptability, although fresh carrots obtained higher scores.

Fresh raw carrots were also preferred in overall acceptability to stored raw carrots, with scores of 0.92 and 0.79 respectively based on the $+2,-2$ seale.

On the basis of overall quality of fresh and stored raw carrots all cultivars were aceeptable when evaluated fresh and after storage except for Casey. All cooked carrots were well accepted by the panelists except stored Nuggeteer.

\section{RESUMEN}

Cultivo y aceptación de algunas cultivares de zanahoria

En el Centro de Investigación y Desarrollo de Fortuna se probaron seis variedades de zanahoria: Short 'n Sweet, Royal Chantenay, Casey, Royal Danvers, Texun y Nuggeteer. El cenfro está localizado en la costa sur de Puerto Rico considerada como el área principal para la producción de hortalizas en escala comercial. Las zanahorias se sembraron en un suelo San Antón (franco-arcilloso), el cual es prácticamente llano en un cono aluvial de la región semiárida de Puerto Rico.

La calidad de las variedades de zanahoria la evaluó sensorialmente un grupo de cafadores. Las muestras se evaluaron freseas y almacenadas por 30 días a temperatura de $7.2^{\circ} \mathrm{C}\left(45^{\circ} \mathrm{F}\right)$ ralladas crudas o cocidas enteras en agua con sal. Tomando en consideración la aceptabilidad general frescas y almacenadas, todas fueron aceptables con excepción de la variedad Casey. En la evaluación de zanahorias cocidas, la única que fue rechazada fue Nuggeteer, luego de almacenada.

\section{LITERATURE CITED}

1. Agriealtural Research Service, USDA, 1975. Nutritive Value of American Foods in Common Units. Agric. Handb. 456. Washington, D.C.

2. Fernández, C., 1964. Variation of B-carotene and ascorbic acid contents of lettuce and carrots as influenced by seasonal changes in Puerto Rico. J. Agric. Univ. P. R. 48 (1): $39-48$. 
3. Church, C. and H. Church, 1975. Food values of portions commonly used. J. B. Lippincott, Philadelphia, 12 th ed.

4. Heintz, C. M. and A. Kader, 1983. Procedures for the sensory evaluation of horticultural erops. Horti. Sci. 18 (1).

5. Larmond, E., 1977. Laboratory methods for sensory evaluation of food. Publ, 1687. Can. Dep. Agric., Otawa, Ontario.

6. National Research Council. Food and Nutrition Board, 1980. Recommended dietary allowances, 9th revised edition. Washington, D.C.

7. Pergam, D. R. and F. J. Pilgrim, 1957. Hedonic seale method for measuring food preferences, Food Technol. 11 (9) Incert 9.

8. Gierbolini, R. E., 1979. Soil survey of the Ponce area of southern Puerto Rico. Soil Conservation Service, USDA, in cooperation with the University of Puerto Rico, College of Agricultural Sciences.

9. Winters, H. F, and Miskimen, G. W., 1967. Vegetable gardening in the Caribbean area. Agrie. Handb. 323, Agrie. Res. Serv., USDA.

10. Yamaguchi, M., 1983. World vegetables-prineiples, production and nutritive values. AVI Publishing Co., Inc. Westport, Connecticut. 